\title{
Model Pembelajaran Contextual Teaching And Learning (CTL) Berbantu Media Miniatur Lingkungan Untuk Meningkatkan Hasil Belajar IPS
}

\author{
Wahyu Bagja Sulfemi' ${ }^{1}$, Nunung Yuliani ${ }^{2}$ \\ ${ }^{1}$ STKIP Muhammadiyah Bogor, ${ }^{2}$ SDN Kebon Sirih 01 Pagi Jakarta \\ 1'wahyubagja@gmail.com, ${ }^{2}$ yuliani1975nuug@gmail.com
}

\begin{abstract}
Classroom Action Research (CAR) was carried out on students in class III Pancoranmas 5 Elementary School Depok as many as 30 students consisting of 17 men and 13 women. This study aims to improve learning outcomes of the Social Sciences Subject using media-assisted contextual teaching and learning (CTL) learning models. Media Miniature Natural and Artificial Environment. In pre-cycle learning, the average grade 49 was obtained, which was completed by 8 people or $26.67 \%$, observations of teachers who had the courage and were able to answer the teacher's questions for only 5 students or 16.67\%. rose to 68, the complete number of students was 16 or $53.33 \%$, the observations of teachers who were able to answer the teacher's questions correctly reached 16 or $53.33 \%$. Activity Cycle 2, the average grade gain rose significantly to 94, which was completed as much as 28 or 93.34\%. The observations of teachers who have the courage and are able to answer the teacher's questions correctly are 29 or $96.67 \%$. The use of media-assisted Contextual Teaching and Learning (CTL) models The Natural and Artificial Environment Miniature provides a real experience, high-level thinking, learner-centered, critical and creative, meaningful knowledge in life, close to real life, changes in behavior and knowledge. In addition, student learning outcomes can increase.
\end{abstract}

Keywords: Social Sciences, contextual teaching and learning, and Miniature

\section{Pendahuluan}

Seorang guru yang memiliki kompetensi yang maksimal, maka dapat menciptakan persepsi positif di mata peserta didik. Apa yang dilihat peserta didik mengenai kemampuan guru dalam mengajar dapat mempengaruhi persepsi peserta didik pada guru tersebut. Dalam persepsi adakalanya persepsi tersebut baik dan adakalanya juga persepsi tersebut buruk. Bila rangsangan yang diterima peserta didik itu baik, maka peserta didik akan mempersepsikan kemampuan guru dengan baik dan akan berakibat baik pada prestasi belajarnya. Persepsi peserta didik tentang kompetensi guru sangat berpengaruh terhadap prestasi belajar peserta didik, sehingga perlu adanya peningkatan kompetensi pedagogik guru untuk mencapai prestasi yang membanggakan. usaha guru untuk meningkatkan prestasi belajar peserta didik, guru diharapkan mampu bertindak sebagai organisatoris pengajaran, menjadi fasilisator belajar peserta didik, dan dalam hal yang teknis guru tersebut mampu membimbing belajar peserta didik Sulfemi (2016). Dengan kata lain guru ikut bertanggung jawab atas keberhasilan belajar peserta didik, meskipun kesemuanya itu kembali kepada peserta didik selaku obyek sekaligus subyek pendidikan.

Sesuai dengan hasil pengamatan observasi penelitian hasil belajar di Sekolah Dasar Negeri (SDN) Kebon Sirih 01 Pagi Jakarta kelas III Mata Pelajaran IPS tentang "Lingkungan Alam dan Buatan" dengan Kriteria Ketuntasan Maksimum (KKM) 70 diperoleh rata-rata peserta didik rata-rata kelas III 9. Peserta didik yang tuntas sebanyak 8 anak dari 30 peserta didik atau 26,67\%. Peserta didik yang belum tuntas sebanyak 22 anak dari 30 peserta didik atau $73,33 \%$. Hasil pengamatan guru pada saat pembelajaran prasiklus yang memiliki keberanian dan mampu jawab pertanyaan guru dengan benar baru mencapai 5 anak dari 30 peserta didik atau $16,67 \%$, sedangkan yang belum menjawab dengan benar sebanyak 25 anak dari 30 peserta didik atau 83,33\%. Berdasarkan data tersebut peserta didik tidak mampu menerima informasi yang disampaikan sesuai dengan tujuan yang telah di tetapkan oleh guru dengan merujuk pada tidak tercapainya KKM Mata Pelajaran IPS.

Rendahnya hasil belajar tersebut banyak faktor, terutama factor guru dan peserta didik. Guru sebagai komponen penting dalam proses belajar mengajar mempunyai peran yang sangat strategis dalam usaha pembentukan sumber daya manusia berkualitas. Dalam hal ini guru

DOI: 10.33603/ejpe.v7i2.1970

This is an open access article under the CC-BY-SA license 
melaksanakan tugasnya baik sebagai perencana pengajaran, sebagai pelaksana, maupun sebagai evaluator pengajaran. Bahkan guru diharapkan memodifikasi rancangan dan pelaksanaan pengajaran, berperan aktif serta menempatkan kedudukannya sebagai tenaga profesional, sesuai dengan tuntutan masyarakat yang semakin berkembang untuk meningkatkan hasil belajar peserta didik sesuai dengan harapan. Masalah yang paling mendasar yang dikeluhkan oleh peserta didi adalah peserta didik merasa bosan dan jenuh dengan proses kelas karena aktivitas peserta didik yang hanya sebatas mendengarkan penjelasan dari guru saja tanpa berperan aktif dalam proses pembelajaran. (Sulfemi dan Qodir. 2017).

Permasalahan tersebut di atas harus segera dicari solusi pemecahannya, agar tidak memberi dampak pada rendahnya penguasaan konsep dan hasil belajar kelas III SDN Kebon Sirih 01 Pagi Jakarta Mata Pelajaran IPS tentang "Lingkungan Alam dan Buatan" serta mempengaruhi mutu pendidikan. Untuk mengatasi permasalahan di atas peneliti mencoba menerapkan model pembelajaran yang mengarah dan berpusat pada peserta didik dengan memfasilitasi alat bantu, media dan sumber belajar yang memadai

Bertitik tolak pada hal tersebut maka model pembelajaran merupakan salah satu unsur dalam proses pembelajaran yang dapat membantu peserta didik mendapatkan informasi, ide, keterampilan, cara berpikir, dan mengekspresikan ide. Dengan hal ini pondasi utama pembelajaran yang baik adalah konstruktivisme, yaitu model pembelajaran langsung, pembelajaran kooperatif dan pembelajaran berbasis masalah. Pendekatan yang cocok untuk pembelajaran berbasis konstruktivisme adalah Pembelajaran Kontekstual atau Contextual Teaching and Learning (CTL). Demikian pula media pembelajaran yang digunakan oleh guru dalam proses pembelajaran memiliki andil untuk menjelaskan hal-hal yang abstrak dan menunjukan hal-hal yang tersembunyi. Ketidakjelasan atau kerumitan materi pembelajaran dapat dibantu dengan menghadirkan media sebagai perantara. Bahkan dalam hal-hal tertentu media dapat mewakili kekurangan guru dalam mengkomunikasikan materi pelajaran.

Berdasarkan latar belakang masalah yang dipaparkan di atas, dapat dirumuskan masalahnya adalah bagaimana penggunaan model pembelajaran contextual teaching and learning (CTL) berbantu media Media Miniatur Lingkungan Alam dan Buatan dalam meningkatkan hasil Belajar peserta didik Mata Pelajaran Ilmu Pengetahuan Sosial Kelas III di SDN Kebon Sirih 01 Pagi Jakarta.

Menurut Uno (2011) mendefinisikan hakikat belajar adalah "kegiatan yang dilakukan secara sadar untuk menghasilkan suatu perubahan, menyangkut pengetahuan, keterampilan, sikap, dan nilai-nilai”. Sejalan dengan pendapat tersebut Dalyono, M. (2009), belajar adalah suatu proses usaha yang dilakukan seseorang untuk memperoleh suatu perubahan tingkah laku yang baru secara keseluruhan, sebagai hasil pengalamannya sendiri dalam interaksi dengan lingkungannya. Sementara itu, menurut Santrock dan Yussen (1994) dalam Sugihartono, dkk (2007: 74) menyebutkan belajar sebagai "perubahan yang relatif permanen karena adanya pengalaman".

Menurut Anitah (2014) hasil belajar adalah kulminasi dari suatu proses yang telah dilakukan dalam belajar yang menunjukkan suatu perubahan tingkah laku yang baru dari peserta didikyang bersifat menetap, fungsional, positif, dan disadari. Hasil bealajar menurut Bloom mencakup tiga aspek yaitu aspek kognitif, afektif, dan psikomor. Sedangkan menurut Gagne lima tipe hasil belajar yang dapat dicapai peserta didik yaitu motor skills, verbal information, intelektual skills, attitude, dan cognitive strategies.

Ahmadi (2009) menjelaskan bahwa Ilmu Pengetahuan Sosial adalah ilmu-ilmu sosial yang dipilih dan disesuaikan bagi program pendidikan di sekolah atau bagi kelompok belajar yang sederajat. Di dalam berisi seperangkat fakta, peristiwa, konsep, generalisasi yang

p-ISSN 2337-571X | e-ISSN 2541-562X

(CProdi Pendidikan Ekonomi Unswagati Cirebon 
berkaitan dengan perilaku manusia untuk membangun dirinya, masyarakat, bangsa dan lingkungannya. Berdasarkan kepada pengalaman masa lampau yang dapat dimaknai untuk masa kini dan diantisipasi untuk masa yang akan datang.

Menurut Puskur (2001) dan Sulfemi. (2014) IPS adalah suatu bahan kajian terpadu yang merupakan penyederhanaan, adaptasi, seleksi dan modifikasi diorganisasikan dari konsepkonsep ketrampilan-ketrampilan Sejarah, Geografi, Sosiologi, Antropologi, dan Ekonomi. Istilah IPS di sekolah dasar merupakan nama mata pelajaran yang berdiri sendiri sebagai integrasi dari sejumlah konsep disiplin ilmu sosial, humaniora, sains bahkan berbagai isu dan masalah sosial kehidupan. Materi IPS untuk jenjang sekolah dasar tidak terlihat aspek disiplin ilmu karena lebih dipentingkan adalah dimensi pedagogik dan psikologis serta karakteristik kemampuan berpikir peserta didik yang bersifat holistik.

Berdasarkan penjelasan diatas dapat disimpulkan bahwa IPS adalah ilmu pengetahuan yang membahas mengenai gejala-gejala dan masalah kehidupan sosial di masyarakat. Dengan demikian Hasil Belajar IPS adalah Peserta didik perlu mempelajari IPS supaya peserta didik mampu menunjukkan perubahan perilaku yang lebih baik dalam kehidupan sehari-hari baik di rumah, sekolah maupun di masyarakat. Dengan demikian hasil Belajara IPS adalah hasil yang dicapai oleh peserta didik selama berlangsungnya proses belajar mengajar IPS dalam jangka waktu tertentu, umumnya hasil belajar dalam sekolah berbentuk pemberian nilai

Menurut Sanjaya (2009) contextual teaching and learning (CTL) merupakan suatau startegi pembelajaran yang menghubungkan antara konten pelajaran dengan situasi kehidupan nyata, dan mendorong peserta didik mengkaitkan antara pengetahuan dan pengalaman yang didapatnya disekolah dengan kehidupannya sebagai anggota keluarga, warga negara, dan dunia kerja.

Setiawan, (2007) menyampaikan bahwa CTL adalah sebuah sistem yang menyeluruh. CTL terdiri dari bagian-bagian yang saling terhubung. Jika bagian-bagian ini terhubung satu sama lain, maka akan dihasilkan pengaruh yang melebihi hasil yang diberikan bagianbagiannya secara terpisah. Selanjutnya Muslich, (2009), menyampaikan pembelajaran kontekstual atau contextual teaching and learning adalah konsep belajar yang membantu guru mengkaitkan antara materi pembelajaran dengan situasi dunia nyata peserta didik, dan mendorong peserta didik membuat hubungan antara pengetahuan yang dimilikinya dengan penerapannya dalam kehidupan mereka sehari-hari. Pengetahuan dan keterampilan peserta didik diperoleh dari usaha peserta didik mengkonstruksi sendiri pengetahuan dan keterampilan baru ketika ia belajar.

Beberapa pendekatan yang digunakan dalam metode Contextual Teaching Learning adalah sebagai berikut: 1) Problem-based learning Problem-based learning, 2) Authentic Instruction Authentic Instruction, 3) Inquiry-Based Learning Inquiry-based learing, 4). Project-Based Learning Project-Based Learning, 5). Work-Based Learning Work-Based Learning, 7) Cooperative Learning Coopertive Learning, yaitu pendekatan pembelajaran yang menggunakan kelompok kecil untuk bekerja sama dalam rangka mengoptimalkan kondisi belajar untuk mencapai tujuan belajar (Yusnita dan Munzir, 2017).

Kelebihan pendekatan pembelajaran kontekstual adalah real world learning, mengutamakan pengalaman nyata, berfikir tingkat tinggi, berpusat pada peserta didik, peserta didik aktif, kritis dan kreatif, pengetahuan bermakna dalam kehidupan, dekat dengan kehidupan nyata, adanya perubahan prilaku, pengetahuan diberi makna, dan kegiatan bukan mengajar tetapi belajar. Selain itu keunggulan lain yakni kegiatan lebih pada pendidikan bukan pengajaran sebagai pembentukan, memecahkan masalah, peserta didik acting guru mengarahkan, dan hasil belajar diukur dengan berbagai alat ukur tidak hanya tes saja.

p-ISSN 2337-571X | e-ISSN 2541-562X

(CProdi Pendidikan Ekonomi Unswagati Cirebon 
Model pembelajaran CTL memiliki beberapa kelemahan pembelajaran kontekstual antara lain, bagi guru kelas, guru harus memiliki kemampuan untuk memahami secara mendalam dan komperhensif tentang konsep pembelajaran kontekstual itu sendiri, potensi perbedaan individual peserta didik di kelas, beberapa pendekatan pembelajaran yang berorientasi kepada aktivitas peserta didik, dan sarana, media, alat bantu serta kelengkapan pembelajaran yang menunjang aktivitas peserta didik dalm belajar. Sedangkan bagi peserta didik yakni inisiatif dan kreatif dalam belajar, memiliki wawasan pengetahuan yang memadai dari setiap mata pelajaran, adanya perubahan sikap dalam menghadapi persoalan, dan memiliki tanggung jawab pribadi yang tinggi dalam menyelesaikan tugas-tugas. (Suprijono, 2009)

Dari pengertian di atas dapat ditarik kesimpulan bahwa pendekatan pembelajaran kontekstual (Contextual Teaching and Learning atau CTL) adalah konsep belajar yang membentuk guru menghubungkan antara materi pelajaran yang diajarkannya dengan situasi dunia nyata peserta didik dan mendorong membuat hubungan antara pengetahuan yang dimilikinya dengan penerapannya dalam kehidupan mereka sehari-hari.

Media menurut Winataputra (2010) berasal dari bahasa latin merupakan bentuk jamak dari kata "medium" yang secara harfiah berarti "perantara" (between) yaitu perantara sumber pesan (source) dengan penerima pesan (receiver). Dalam bahasa Arab, media adalah perantara atau pengantar pesan dari pengirim kepada penerima. Menurut Azhar (2014) menngatakan bahwa media apabila dipahami secara garis basar adalah manusia, materi, atau kejadian yang membangun kondisi yang membuat peserta didik mampu memperoleh pengetahuan, keterampilan atau sikap.

Menurut Rokhimat (2003) media pembelajaran mempunyai fungsi untuk meningkatkan kualitas belajar mengajar dan dapat mengurangi verbalisme para peserta didik, sehingga melalui media pembelajaran guru dapat lebih mengefektifkan pencapaian tujuan pembelajaran. Perencanaan pengadaan kebutuhan media pendidikan didasarkan pada persyaratan dan perhitungan dari segi kualitas dapat dipertanggung jawabkan dan dari segi kuantitas dapat mencukupi kebutuhan sekolah.

Dari uraian para ahli diatas maka penulis dapat mengambil kesimpulan bahwa media pembelajaran penyalur atau perantara pesan-pesan pembelajaran yang disampaikan oleh sumber pesan (guru) kepada penerima pesan (peserta didik) dalam bentuk tercetak, audiovisual dan peralatan dengan maksud agar pesan-pesan tersebut dapat diserap cepat dan tepat sesuai dengan tujuan pembelajaran. Media yang digunakan adalah media Miniatur Lingkungan Alam dan Buatan.

\section{Metode Penelitian}

Subjek Penelitian ini adalah peserta didik kelas III SDN Kebon Sirih 01 Pagi Jakarta. Peserta didik yang dijadikan objek penelitian sebanyak 30 orang peserta didik yang terdiri dari 17 orang laki-laki orang dan 13 orang perempuan. Alasan peneliti melakukan Penelitian Tindakan Kelas disekolah ini karena SDN Kebon Sirih 01 Pagi Jakartamerupakan tempat bertugas peneliti mengajar. Selain itu dikarenakan peserta didik belum memahami materi Mata Pelajaran IPS tentang Lingkungan Alam dan Buatan ini di lihat dari nilai ratarata peserta didik dibawah KKM. Hal inilah yang menjadi motivasi peneliti untuk dilakukan penelitian dengan tujuan untuk memperbaiki proses belajar mengajar dan meningkatkan hasil belajar peserta didik Mata Pelajaran IPS di SDN Kebon Sirih 01 Pagi Jakarta.

Penelitian ini merupakan jenis penelitian tindakan kelas atau Classroom Action Research yaitu penelitian yang dilakukan di kelas. Sehubungan dengan ini Arikounto (2006) menyatakan penelitian tindakan kelas adalah suatu penelitian yang akar masalahnya muncul di kelas, dan dirasakan langsung oleh guru yang bersangkutan.

p-ISSN 2337-571X | e-ISSN 2541-562X

(CProdi Pendidikan Ekonomi Unswagati Cirebon 
Penelitian ini menggunakan analisis dengan perhitungan kuantitatif sederhana dan kualitatif deskripsi. Peneliti akan menganalisis data kuantitatif melalui hasil perbedaan persentase antara kemampuan awal (pre test) akhir siklus 1 dan akhir siklus 2 yang didasarkan data yang diperoleh di lapangan. Data tersebut berupa hasil pengamatan yang akan dilakukan peneliti dan kolaborator. Teknik analisis data yang terkumpul akan dilakukan dengan persentase. Teknis analisis data dilakukan untuk melihat perbedaan signifikansi kecerdasan interpersonal saat assesmen awal dengan assesmen akhir atau setelah tindakan. Hal tersebut dilakukan untuk dapat mengetahui perbedaan nilai sebelum dan sesudah intervensi tindakan. Selain menggunakan pendekatan kuantitatif, peneliti juga menggunakan pendekatan kualitaitif. Analisis

Adapun data diperoleh peneliti mengumpulan data yang digunakan oleh peneliti adalah dengan observasi, Wawancara dan Dokumentasi. Data yang dikumpulkan pada setiap kegiatan penelitian dari pelaksanaan siklus penelitian dianalisis secara deskriptif dengan menggunakan teknik persentase untuk melihat kecendrungan yang terjadi dalam kegiatan pembelajaran mata pelajaran IPS. Pada prasiklus tekhik pengumpulan data dilakukan dengan tes tertulis berbentuk isian singkat sebanyak 10 soal. Sedangkan pada siklus pertama teknik pengumpulan data dilakukan dengan tes tertulis dalam bentuk pilihan ganda 5 soal dan isian singkat 10 soal. Sedangkan siklus kedua teknik pengumpulan data dilakukan dengan cara: 1) Tes tertulis berbentuk pilihan ganda 5 soal, isian singkat 5 soal dan uraian terbatas 5 soal.2). Diskusi dengan teman sejawat tentang keberhasilan dan kekurangan atau kelemahan dalam pelaksanaan pembelajaran melalui metode pembelajaran demonstrasi dan media audio visual, termasuk merefleksi hasil setiap siklus untuk perbaikan-perbaikan aktivitas dan praktik pembelajaran yang akan datang.

\section{Hasil dan Pembahasan}

Dalam pelaksanaan Penelitian dilakukan melalui dua siklus. Siklus pertama merupakan perbaiakan dari pembelajaran awal (prasiklus), dimana hasil belajar peserta didik belum sesuai apa yang diharapkan. Sedangkan pada siklus kedua merupakan perbaikan dari siklus pertama untuk meingkatkan motivasi dan hasil belajar peserta didik sehingga sesuai yang diharapkan. Lama pembelajaran tiap siklus adalah 2 x 35 menit (2 jam pelajaran). Selama kegiatan perbaikan pembelajaran penulis dibantu oleh teman sejawat untuk membantu mengobservasi dan memberi masukan dimana kelemahan guru dan peserta didik dalam kegiatan pembelajaran.

Kegiatan Prasiklus yang merupakan kondisi awal hasil belajar peserta didik di SDN Kebon Sirih 01 Pagi Jakarta kelas III Mata Pelajaran IPS tentang "Lingkungan Alam dan Buatan". Pada pelaksanaan Prasiklus dengan menggunakan metode konvensional ceramah dengan media papan tulis, buku IPS kalas 3 SD dan LKS diperoleh hasil belajar sebagai berikut : jumlah nilai keseluruahan yaitu 1470, rata-rata kelas 49, nilai tertinggi 70, dan nilai terendah 30 atas nama Muhamad Ibnu. A, Muhamad Rafi AB, Melati Apriliana, dan Reqia Hana Praka. Hasil pengamatan guru pada saat pembelajaran prasiklus yang memiliki keberanian dan mampu jawab pertanyaan guru dengan benar baru mencapai 5 anak dari 30 peserta didik atau $16,67 \%$ atas nama peserta Akbar Rabbani. K, Bintang Juviar, Dimas Suhendra, Haura Tsabitah Alwafi, dan M. Risky Fahreja. Sedangkan yang belum menjawab dengan benar sebanyak 25 anak dari 30 peserta didik atau 83,33\%.

Peserta didik yang tuntas berdasarkan hasil belajar sebanyak 8 anak dari 30 peserta didik atau $26,67 \%$. Peserta didik yang belum tuntas sebanyak 22 anak dari 30 peserta didik atau 73,33\%. Hasil perhitungan interval nilai hasil belajar IPS pada Prasiklus diperoleh rentang 40, banyak kelas interval 5,37 dan panjang kelas interval (p) diperoleh 5,71 dibulatkan menjadi 6 . Berdasarkan data hasil perhintungan interval diperoleh yang berada di rentang nilai $30-37$

p-ISSN 2337-571X | e-ISSN 2541-562X

(CProdi Pendidikan Ekonomi Unswagati Cirebon 
terdapat 4 peserta didik, rentang nilai 38 - 45 terdapat 3 peserta didik, rentang nilai $46-53$ terdapat 3 peserta didik, rentang nilai $54-61$ terdapat 0 peserta didik, $62-69$ terdapat 0 peserta didik, dan rentang nilai 70 - 77 terdapat 8 peserta didik

Kegiatan Prasiklus yang merupakan kondisi awal hasil belajar peserta didik di SDN Kebon Sirih 01 Pagi Jakarta kelas III Mata Pelajaran IPS tentang "lingkungan alam dan buatan". Pada pelaksanaan prasiklus dengan menggunakan metode konvensional ceramah dengan media papan tulis, buku IPS kalas 3 SD dan LKS diperoleh hasil belajar yang tidak memenuhi Ketuntasan Kriterian Maksimum (KKM) maka dilanjutkan ke siklus 1 dengan menggunakan model pembelajaran kontektual atau Contextual Teaching and Learning (CTL) dengan media papan tulis, buku paket dan LKS. Hasil kegiatan pada prasiklus sesuai dengan penelitian dari (Sulfemi dan Nurhasanah, 2018)

Pada kegiatan Siklus 1 yang merupakan perbaikan hasil belajar peserta didik dengan KKM 70 diperoleh hasil belajar sebagai berikut : jumlah nilai keseluruahan yaitu 2040, ratarata kelas 68, nilai tertinggi 85 atas nama Muhamad Ibnu. A, dan Juan Christian, nilai terendah 60 , peserta didik yang tuntas berdasarkan hasil belajar sebanyak 16 anak dari 30 peserta didik atau $53,33 \%$, peserta didik yang belum tuntas sebanyak 14 anak dari 30 peserta didik atau 46,67\% Hasil pengamatan guru pada saat pembelajaran Siklus 1 peserta didik yang memiliki keberanian dan mampu jawab pertanyaan guru dengan benar baru mencapai 16 anak dari 30 peserta didik atau 53.33\%. Sedangkan yang belum menjawab dengan benar sebanyak 14 anak dari 30 peserta didik atau $46,67 \%$.

Hasil perhitungan interval nilai hasil belajar IPS pada Prasiklus diperoleh rentang 25, banyak kelas interval 6,88 dibulatkan menjadi dan panjang kelas interval (p) diperoleh 3,57 dibulatkan menjadi 4 . Berdasarkan data hasil perhintungan interval kelas yang berada berada di rentang nilai $60-67$ terdapat 14 orang peserta didik, rentang nilai $68-75$ terdapat 10 orang peserta didik, rentang nilai $76-83$ terdapat 4 orang peserta didik, dan rentang nilai $84-91$ terdapat orang peserta didik.

Kegiatan Siklus 1 yang merupakan perbaikan hasil belajar peserta didik di SDN Kebon Sirih 01 Pagi Jakarta kelas III Mata Pelajaran IPS tentang "Lingkungan Alam dan Buatan" tidak mencapai KKM maka dilakukan pembelajaran ke Siklus 2. Pada pelaksanaan Siklus 2 dengan menggunakan model pembelajaran kontektual atau atau Contextual Teaching and Learning (CTL). Setelah berdiskusi dengan teman sejawat maka dibutuhkan media dalam pembelajaran untuk itu maka dilakukan penambahan media yaitu Media miniatur lingkungan alam. Pada kegiatan siklus 2 yang merupakan perbaikan hasil belajar peserta didik dengan KKM 70 diperoleh jumlah nilai keseluruahan yaitu 2823, rata-rata kelas 94, nilai tertinggi 100, dan nilai terendah 60 yaitu atas nama Muhamad Faris. Peserta didik yang tuntas berdasarkan hasil belajar sebanyak 28 anak dari 30 peserta didik atau 93.34\%. Peserta didik yang belum tuntas sebanyak 2 anak dari 30 orang peserta didik atau $6.66 \%$.

Hasil pengamatan guru pada saat pembelajaran Siklus 2 yang memiliki keberanian dan mampu jawab pertanyaan guru dengan benar baru 29 anak dari 30 orang peserta didik atau $96,67 \%$. Sedangkan yang belum menjawab dengan benar sebanyak 1 anak dari 30 orang peserta didik atau 3,33\% atas nama Muhamad Faris. Untuk melihat lebih jelas berikut disampaikan tabel hasil belajar dan pengamatan guru pada pembelajaran Siklus 2 pada mata pelajaran IPS tentang "lingkungan alam dan buatan"

Hasil perhitungan interval nilai hasil belajar IPS pada siklus 1 diperoleh rentang 40, banyak kelas interval 5,37 dibulatkan menjadi 6, dan panjang kelas interval (p) diperoleh 5,71 dibulatkan menjadi 6 . Berikut hasil perhitungan interval kelas peserta didik yang berada di rentang nilai $60-67$ terdapat 2 orang peserta didik, rentang nilai $68-75$ terdapat 1 peserta didik, rentang nilai $76-83$ terdapat 1 orang peserta didik, rentang nilai $84-91$ terdapat 2 orang

p-ISSN 2337-571X | e-ISSN 2541-562X

CProdi Pendidikan Ekonomi Unswagati Cirebon 
peserta didik, 92 - 99 terdapat 11 orang peserta didik, dan rentang nilai 100 terdapat 13 orang peserta didik. Berikut rangkuman hasil belajar peserta didik dan hasil pengamatan belajar peserta didik Mata Pelajaran IPS setiap siklus yang disajikan dalam tebel dan grafik berikut ini

Tabel 1. Persentase Keberhasilan Hasil Belajar Peserta Didik

\begin{tabular}{ccccccccc}
\hline \multirow{2}{*}{ No. } & \multirow{2}{*}{ Kriteria } & \multicolumn{2}{c}{ Prasiklus } & \multicolumn{2}{c}{ Siklus 1 } & \multicolumn{2}{c}{ Siklus 2 } \\
\cline { 3 - 9 } & & Jumlah & $\%$ & Jumlah & $\%$ & Jumlah & $\%$ \\
\hline $\mathbf{1}$ & Tuntas & 8 & 26,67 & 16 & 53,3 & 28 & 93.34 \\
\hline $\mathbf{2}$ & Belum Tuntas & 22 & 73,33 & 14 & 46,67 & 2 & 6,66 \\
\hline $\mathbf{3}$ & Nilai Rerata & & 49 & & \multicolumn{2}{c}{68} & \multicolumn{3}{c}{94} \\
\hline
\end{tabular}

Sumber: Hasil Penelitian 2018

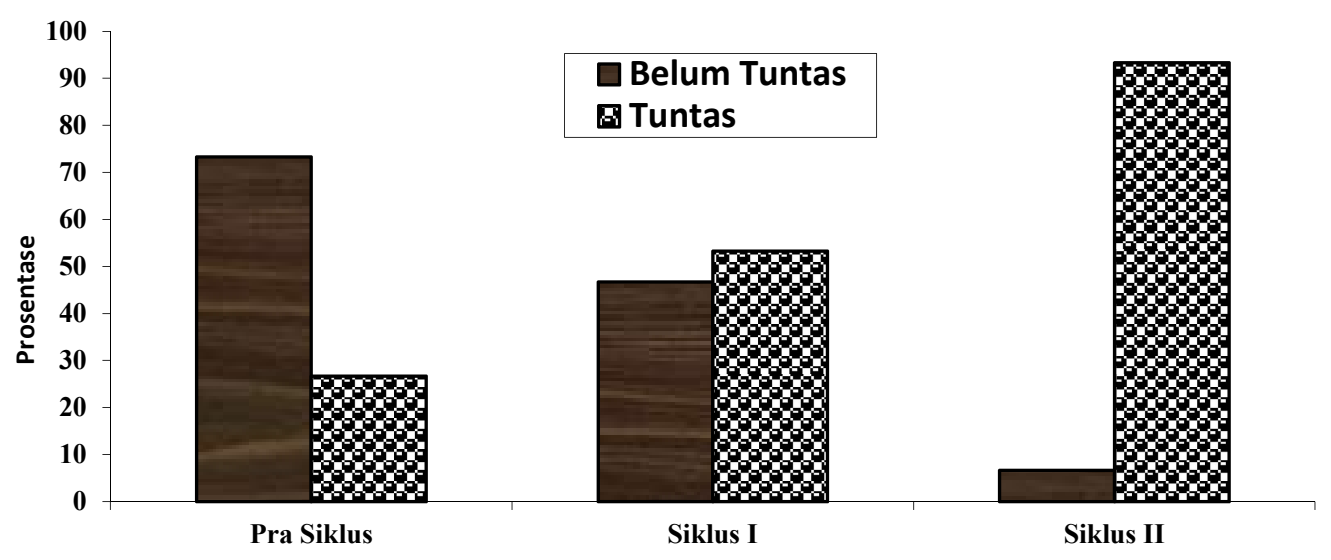

Sumber: Hasil Penelitian 2018

Gambar 1. Grafik Ketuntasan Belajar Peserta Didik Setiap Siklus

Penelitian Tindakan kelas yang dilakukan perolehan nilai ketuntasan belajar pada prasiklus, siklus I dan siklus II terus mengalami peningkatan. Demikian pula dengan pengamatan guru yang mengalami peningkatan. Hal ini menunjukan pemahaman peserta didik terhadap pembelajaran meningkat pula.

Tabel 2. Persentase Hasil Pengamatan Belajar Peserta Didik

\begin{tabular}{cccccccc}
\hline \multirow{2}{*}{ No. } & \multirow{2}{*}{ Kriteria } & \multicolumn{2}{c}{ Prasiklus } & \multicolumn{2}{c}{ Siklus 1 } & \multicolumn{2}{c}{ Siklus 2 } \\
\cline { 2 - 8 } & & Jumlah & $\%$ & Jumlah & $\%$ & Jumlah & $\%$ \\
\hline $\mathbf{1}$ & Dapat Menjawab & 5 & 16,67 & 16 & 53.33 & 1 & 96,67 \\
\hline $\mathbf{2}$ & Tidak Dapat Menjawab & 25 & 83,33 & 14 & 46,67 & 29 & 3,33 \\
\hline $\mathbf{3}$ & Jumlah & 30 & 100 & 30 & 100 & 30 & 100 \\
\hline
\end{tabular}

Sumber: Hasil Penelitian 2018

Kegiatan Prasiklus yang merupakan kondisi awal hasil belajar peserta didik di SDN Kebon Sirih 01 Pagi Jakarta kelas III Mata Pelajaran IPS tentang "lingkungan alam dan buatan". Pada pelaksanaan prasiklus dengan menggunakan metode konvensional ceramah dengan media papan tulis, buku IPS kalas 3 SD dan LKS diperoleh jumlah nilai keseluruahan yaitu 1470 , rata-rata kelas 49 , nilai tertinggi 70 , dan nilai terendah 30 . Peserta didik yang tuntas 
berdasarkan hasil belajar sebanyak 8 anak dari 30 peserta didik atau 26,67\%. Peserta didik yang belum tuntas sebanyak 22 anak dari 30 peserta didik atau 73,33\%. Hasil pengamatan guru pada saat pembelajaran prasiklus yang memiliki keberanian dan mampu jawab pertanyaan guru dengan benar baru mencapai 5 anak dari 30 orang peserta didik atau 16,67\%, sedangkan yang belum menjawab dengan benar sebanyak 25 anak dari 30 peserta didik atau 83,33\%.

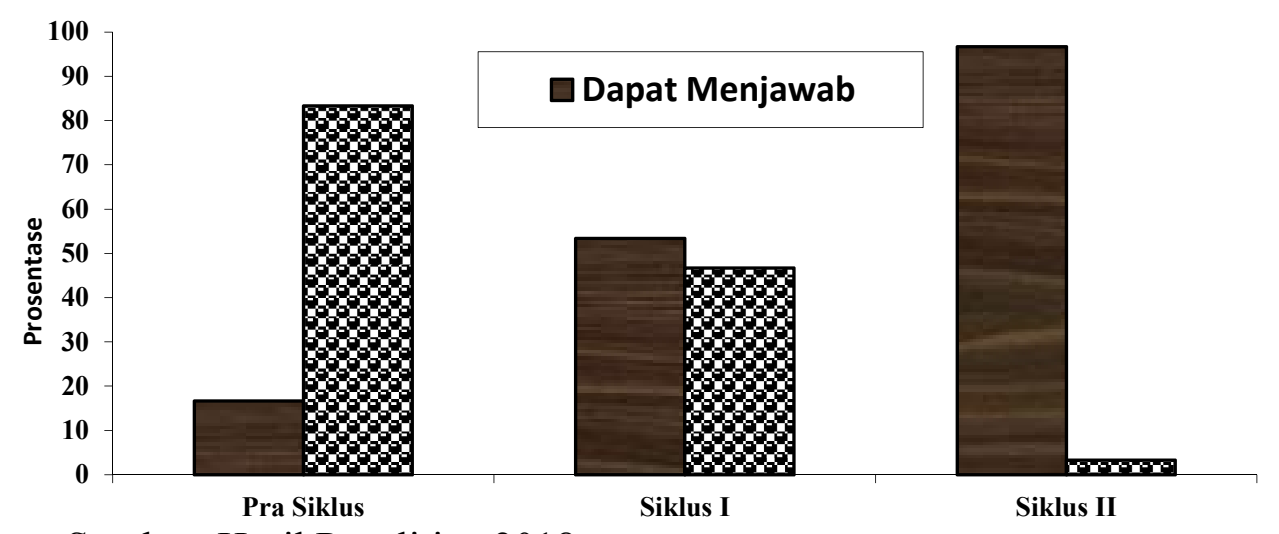

Sumber: Hasil Penelitian 2018

Gambar 2. Grafik Pengamatan Guru Terhadap Peserta Didik yang Dapat Menjawab dan Tidak Dapat Menjawab

Rendahnya minat, motivasi, rendahnya hasil belajar dan peserta didik kurang aktif dalam proses pembelajaran, hal ini terbukti dengan sedikit sekali peserta didik yang bertanya, sedikit sekali peserta didik yang dapat menjawab pertanyaan yang diajukan oleh guru, tidak adanya diskusi, dan tidak ada kerjasama Mata Pelajaran IPS dengan tema Lingkungan Alam Mata dan Buatan disebabkan karena hal berikut ini : 1). model pembelajaran yang digunakan kurang menarik dimana guru menjadi teacher center sehingga banyak peserta didik yang kesulitan memahami materi, 2) penggunaa metode pembalajaran yang tidak menarik, bervariasi dan efektif yang sesuai secara maksimal sehingga peserta didik mengalami kesulitan, 3) tidak adanya penggunaan media pembelajaran yang membuat peserta didik tidak tertarik untuk belajar, 4) Guru jarang mengadakan dan reward kepada umpan balik secara langsung selama pembelajaran, sehingga peserta didik tidak aktif, 5) Guru kurang memberikan kesempatan kepada peserta didik untuk bertanya dan melibatkan peserta didik dalam materi ini, 6) Guru kurang memberikan motivasi pada saat pembelajaran berlangsung sehingga peserta didik tidak tertarik pada pelajaran IPS. Hasil ini juga sesui dengan penelitian Habiba (2017) dan Permatasari, (2017).

Rendah hasil Prasiklus maka peneliti meneruskan Pada kegiatan Siklus 1 yang merupakan perbaikan hasil belajar peserta didik dengan KKM 70 diperoleh jumlah nilai keseluruahan yaitu 2040, rata-rata kelas 68 , nilai tertinggi 85 , dan nilai terendah 60 . Peserta didik yang tuntas berdasarkan hasil belajar sebanyak 16 anak dari 30 orang peserta didik atau $53,33 \%$, peserta didik yang belum tuntas sebanyak 14 anak dari 30 peserta didik atau $46,67 \%$. Hasil pengamatan guru pada saat pembelajaran Siklus 1 peserta didik yang memiliki keberanian dan mampu jawab pertanyaan guru dengan benar mencapai 16 anak dari 30 peserta didik atau 53.33\%. Sedangkan yang belum menjawab dengan benar sebanyak 14 anak dari 30 peserta didik atau 46,67\%. Untuk melihat lebih jelas berikut disampaikan tabel hasil belajar dan pengamatan guru pada pembelajaran Siklus 1 pada mata pelajaran IPS tentang "lingkungan alam dan buatan. 
Ketidak tercapaian hasil belajar peserta didik pada siklus 1 yang tidak mencapai KKM sesuai dengan penelitian Kasmiati, (2017) dan penelitian Yuliana. Et all. (2015). Rendahnya hasil belajar pada Siklus 1 ini sebabkan karena faktor-faktor berikut ini : 1) Tidak adanya penggunaan media pembelajaran yang membuat peserta didik tidak tertarik untuk belajar, 2) Guru jarang mengadakan dan reward kepada umpan balik secara langsung selama pembelajaran, sehingga peserta didik tidak aktif, Guru kurang memberikan kesempatan kepada peserta didik untuk bertanya dan melibatkan peserta didik dalam materi ini, 3) Guru kurang memberikan motivasi pada saat pembelajaran berlangsung sehingga peserta didik tidak tertarik pada pelajaran IPS. Akan tetapi penggunaan metode CTL sudah dapat menaikan hasil belajar peserta didik. Ketidak tercapaian KKM dalam siklus I maka peneulis melanjutkan ke penelitian berikut yaitu perbaikan pembelajaran siklus 2 .

Kegiatan Siklus 2 yang merupakan perbaikan pembelajaran siklus 1 dalam pembelajaran menggunakan model pembelajaran kontektual atau Contextual Teaching and Learning (CTL) dengan media miniatur lingkungan alam mengalami kenaikan signifikan yaitu diperoleh jumlah nilai keseluruahan 2823, rata-rata kelas 94, nilai tertinggi 100, dan nilai terendah 60 . Peserta didik yang tuntas berdasarkan hasil belajar sebanyak 28 anak dari 30 peserta didik atau $93.34 \%$. Peserta didik yang belum tuntas sebanyak 2 anak dari 30 orang peserta didik atau $6.66 \%$.

Hasil pengamatan guru pada saat pembelajaran Siklus 2 yang memiliki keberanian dan mampu jawab pertanyaan guru dengan benar mencapai 29 anak dari 30 orang peserta didik atau 96,67\%. Sedangkan yang belum menjawab dengan benar sebanyak 1 anak dari 30 orang peserta didik atau 3,33\%. Untuk melihat lebih jelas berikut disampaikan tabel hasil belajar dan pengamatan guru pada pembelajaran Siklus 2 pada mata pelajaran IPS tentang "lingkungan alam dan buatan".

Meningkatnya hasil belajar pada siklus 2 karena hal sebagai berikut 1) Penggunaan medel pembelajaran Contextual Teaching and Learning (CTL) dan teknik pembelajaran yang bervariasi dan efektif yang sesuai secara maksimal sehingga peserta didik tidak mengalami kesulitan dan hasil belajar dapat diperoleh secara maksimal, 2) Penggunakan media pembelajaran dengan media miniatur lingkungan alam yang sesuai secara maksimal sehingga terciptanya suasana pembelajaran yang kondusif, dan menyenangkan bagi peserta didik, 3) pemberian motivasi pada saat pembelajaran berlangsung sehingga peserta didik tertarik pada pelajaran IPS, 4) pemberian kesempatan kepada peserta didik untuk bertanya dan melibatkan peserta didik dalam materi, dan 4) berikan reward dan umpan balik secara langsung selama pembelajaran, sehingga peserta didik aktif.

Penggunaan model pembelajaran Contextual Teaching and Learning (CTL) yang menaikan hasil belajar peserta didik ini sesuai dengan yang disampaikan oleh Suprijono (2009:85-88) dan penelitian Yuliana. Et all. (2015), dimana dalam pembelajaran peserta didik memiliki pengalaman nyata, berfikir tingkat tinggi, berpusat pada peserta didik, peserta didik aktif, kritis dan kreatif, pengetahuan bermakna dalam kehidupan, dekat dengan kehidupan nyata, adanya perubahan prilaku, pengetahuan diberi makna, dan kegiatan bukan mengajar tetapi belajar. Selain itu keunggulan lain yakni kegiatan lebih pada pendidikan bukan pengajaran sebagai pembentukan, memecahkan masalah, peserta didik acting guru mengarahkan, dan hasil belajar diukur dengan berbagai alat ukur tidak hanya tes saja.

Demikian pula penggunaan media miniatur lingkungan alam seperti yang disampaikan oleh Rokhimat (2003), hasil penelitian Aliputri, (2018), dan hasil penelitian Darmawan, (2017 : 1-13) behwa media pembelajaran dapat meningkatkan kualitas belajar mengajar dan dapat mengurangi verbalisme para peserta didik, sehingga melalui media pembelajaran guru dapat lebih mengefektifkan pencapaian tujuan pembelajaran. Perencanaan pengadaan kebutuhan

p-ISSN 2337-571X | e-ISSN 2541-562X

(C)Prodi Pendidikan Ekonomi Unswagati Cirebon 
media pendidikan didasarkan pada persyaratan dan perhitungan dari segi kualitas dapat dipertanggung jawabkan dan dari segi kuantitas dapat mencukupi kebutuhan sekolah.

Penggunaan model pembelajaran Contextual Teaching and Learning (CTL) media Miniatur Lingkungan Alam dan Buatan membuat peserta didik termotivasi dan mendapat hasil belajar peserta didik di SDN Kebon Sirih 01 Pagi Jakartakelas III Mata Pelajaran IPS tentang "Lingkungan Alam dan Buatan dapat melebihi KKM yang di tetapkan. Hasil pembelajaran ini dapat tercapainya tujuan Penelitian Tindakan Kelas seperti yang disampaikan Yusnita dan Munzir. (2017) yaitu dapat memperbaiki dan meningkatkan kualitas pembelajaran serta membantu memberdayakan guru dalam memecahkan masalah pembelajaran di sekolah. Pada sisi lain, PTK akan mendorong para guru untuk memikirkan apa yang mereka lakukan seharihari dalam menjalankan tugasnya. Mereka akan kritis terhadap apa yang mereka lakukan tanpa tergantung pada teori-teori yang muluk-muluk yang bersifat universal yang ditemukan oleh para pakar peneliti yang sering kali tidak cocok dengan situasi dan kondisi kelas.

\section{Simpulan}

Berdasarkan hasil penelitian perbaikan pembelajaran yang telah dilaksanakan mulai dari prasiklus, siklus I sampai dengan siklus II di SDN Kebon Sirih 01 Pagi Jakarta kelas III Mata Pelajaran IPS tentang "lingkungan alam dan buatan maka, penulis dapat menarik kesimpulan sebagai berikut : 1) Pada pembelajaran prasiklus diperoleh rata-rata kelas 49, yang tuntas sebanyak 8 peserta didik atau 26,67\%, hasil pengamatan guru yang memiliki keberanian dan mampu jawab pertanyaan guru hanya 5 peserta didik atau 16,67 \%, Pada kegiatan Siklus 1 ratarata kelas naik mejadi 68, yang tuntas sebanyak 16 peserta didik atau 53,33\%, Hasil pengamatan guru yang mampu jawab pertanyaan guru dengan benar mencapai 16 atau 53.33\%. Kegiatan Siklus 2 perolehan rata-rata kelas naik secara sginifikan menjadi 94, yang tuntas sebanyak 28 peserta didik atau 93.34\%. Hasil pengamatan guru yang memiliki keberanian dan mampu jawab pertanyaan guru dengan benar terdapat 29 atau 96,67\%. 2) Penggunaan model pembelajaran Contextual Teaching and Learning (CTL) memberikan pengalaman nyata, berfikir tingkat tinggi, berpusat pada peserta didik, kritis dan kreatif, pengetahuan bermakna dalam kehidupan, dekat dengan kehidupan nyata, adanya perubahan prilaku, pengetahuan. Selain itu hasil belajar peserta didik dapat meningkat 3) Penggunaan media Miniatur Lingkungan Alam dan Buatan meningkatkan kualitas belajar mengajar dan dapat mengurangi verbalisme para peserta didik, sehingga melalui media pembelajaran guru dapat lebih mengefektifkan pencapaian tujuan pembelajaran.

Berdasarkan kesimpulan di atas ada beberapa hal yang sebaiknya dilakukan oleh guru dalam rangka meningkatkan prestasi belajar peserta didik antara lain : 1) Guru membiasakan menganalisis hasil belajar peserta didik secara terus menerus, berkala, terprogram, dan berkesinambangungan. 2) Guru hendaknya mampu menyajikan materi pelajaran IPS dengan pembelajaran Contextual Teaching and Learning (CTL) media Miniatur Lingkungan Alam dan Buatan, sehingga kemampuan peserta didik dapat terus meningkat, 3) Guru diharapkan dapat menmbuhkan dan menciptakan interksi pembelajaran yang kondusif. Sehingga peserta didik dapat belajar dengan baik. 4) Dalam menyampaikan materi pembelajaran kepada peserta didik, diharapkan guru memvariasikan pendekatan Contextual Teaching and Learning (CTL) dengan metode-metode lain yang lebih sesuai dengan kemampuan peserta didik dan karakteristik materi. 5) Kepala sekolah hendaknya mampu menjadi motivator guru untuk menerapkan berbagai model dan media pembelajaran sehingga guru secara terus-menerus melakukan pembaharuan dalam dunia pendidikan. Selain itu, kepala sekolah juga hendaknya menjadi fasilitator, sehingga pembaharuan yang dilakukan guru dalam pembelajaran dapat terealisasi dengan optimal

p-ISSN 2337-571X | e-ISSN 2541-562X

(C)Prodi Pendidikan Ekonomi Unswagati Cirebon 


\section{Referensi}

Ahmadi, A. (2009). Ilmu Sosial Dasar . Jakarta : Rineka Cipta.

Anitah, W. Sri dkk, (2014). Strategi Pembelajaran di SD. Tanggerang Selatan : Universitas Terbuka

Arikunto, S. (2012). Penelitian Tindakan Kelas. Jakarta: Bumi Aksara.

Arsyad, A. (2014). Media Pembelajaran. Jakarta: PT Raja Grafindo Persada.

Aliputri, D. H. (2018). Penerapan Model Pembelajaran Kooperatif Tipe Make A Match Berbantuan Kartu Bergambar Untuk Meningkatkan Hasil Belajar Siswa. Jurnal Bidang Pendidikan Dasar (JBPD), 2. (1A) 70-77.

Darmawan, Anak Agung Gede Agung. (2017). Peningkatanaktivitas dan Hasil Belajar Siswa Dalam Pembelajaran IPS Melalui Metode Demonstrasi pada Kelas VII Semester II di SMP Negeri I Gianyar. Jurnal Ilmiah Ilmu Sosial . 3, (1). 1-13

Dalyono, M. (2009). Psikologi Pendidikan. Jakarta: Rineka Cipta

Daryanto, (2011). Penelitian Tindakan Kelas dan Penelitian Tindakan Sekolah Beserta contohcontohnya. Yogyakarta: Gava Media

Rokhimat (2003). Strategi Belajar Mengajar. Jakarta: Universitas Terbuka.

Muslich, M. (2012). Melaksanakan PTK itu Mudah. Jakarta: Bumi Aksara.

Uno, Hamzah dan Nina Lamatenggo. (2011). Teknologi Komunikasi dan Informasi Pembelajaran. Jakarta : Bumi Aksara (Elaine B.Johnson. Terjemahan). California: Corwin Press,inc.

Sanjaya, W. (2009). Strategi Pembelajaran Berorientasi Standar Proses Pendidikan. Jakarta : Kencana.

Segara, N. B. (2016). The Urgency of Map Literacy and Spatial Thinking for Urban Society. European Journal of Social Sciences Studies. 1(1)

Suprijono, A. (2009). Cooperative Learning: Teori dan Aplikasi Pakem. Yogyakarta: Pustaka Pejalar.

Sulfemi, W. B. (2014). Pengaruh Motivasi dan Lingkungan Sekolah Terhadap Prestasi Belajar Sejarah Di SMA Negeri Leuwilang Kabupaten Bogor. Fascho : Kajian Pendidikan dan Sosial Kemasyarakatan 9 (2), 42-57.

Sulfemi, W. B.. (2016). Kompetensi Profesionalisme Guru Indonesia Dalam Menghadapi MEA. Prosiding Seminar Nasional STKIP Muhammadiyah Bogor. 1 (1), 62-77.

Sulfemi, W. B. dan Qodir, A. (2017). Hubungan Kurikulum 2013 Dengan Motivasi Belajar Peserta Didik di SMK Pelita Ciampea. Edutecno. 17 (2), 1-8.

Sulfemi, W. B. dan Nurhasanah. (2018). Penggunaan Metode Demontrasi dan Media Audio Visual Dalam Meningkatkan Hasil Belajar Peserta Didik Mata Pelajaran IPS. Jurnal Pendas Mahakam. 3 (2). 151-158.

Sulfemi, Wahyu Bagja dan Setianingsih. (2018), Penggunaan Tames Games Tournament (TGT) Dengan Media Kartu Dalam Meningkatkan Hasil Belajar. Journal of Komodo Science Education JKSE. 1 (1), 1-14.

p-ISSN 2337-571X | e-ISSN 2541-562X

(CProdi Pendidikan Ekonomi Unswagati Cirebon 
Winataputra, S. U. (2010). Stategi Belajar Mengajar. Jakarta: Universitas Terbuka.

Yusnita dan Munzir. (2017). Peningkatkan Hasil Belajar Pelajaran IPS Dengan Contextual Teaching Learning Melalui Media Gambar Siswa Sekolah Dasar. Faktor Jurnal Ilmiah Kependidikan. 4 (1), 23-38. 